\title{
Withstanding Persecution as a Corroboration of Legitimacy in the New Testament: Reflections on the Resulting Ethical and Hermeneutical Quandary By James A. Kelhoffer
}

\begin{abstract}
Assertions of standing, authority, and power claimed on the basis of withstanding persecution play a prominent and heretofore under-appreciated role in much of the New Testament literature. Yet deriving legitimacy from persecution presents an interpretive quandary not unlike those inherited from biblical passages that condone slavery or unhealthy attitudes toward women and men. Reflection on how we construe ourselves in relation to suffering is an agendum inadequately realized in the New Testament that commends itself for twenty-first century ethics and theology.
\end{abstract}

Key Terms: persecution, legitimation, New Testament ethics, martyrdom, authority

"Was there then a value in human suffering?

'Ah, there is nothing more difficult than answering that question."'1

One task of New Testament (NT) Christology is to define how the NT authors appraised the value of Jesus' suffering and its benefits for humanity. This article considers the reflection of several NT authors that the suffering of Jesus' followers likewise has some value, a reflection that arises as a natural inference from treasuring Jesus' passion. ${ }^{2}$ I argue that assertions of standing, authority, and power claimed on the basis of withstanding persecution play a prominent and heretofore under-appreciated role in much of the NT literature. Afterward, I suggest that reflection on how we today might construe our religious identity in relation to suffering is an agendum inadequately realized in the NT, an agendum that commends itself for twenty-first century ethics and theology. Consequently, deriving legitimacy from persecution presents a quandary not unlike those inherited from biblical passages that condone slavery or unhealthy attitudes toward women.

\section{Persecution and Suffering in the New Testament}

Colossians 1:24 offers a prime example of such reflection, where the Paul of Colossians compares the value of his "sufferings" $(\pi \alpha \theta \eta \dot{\eta} \mu \alpha \tau \alpha)$ with that of Christ's "afflictions" ( $\theta \lambda i \psi \varepsilon \varepsilon \varsigma)$ "for the sake of" ( $v \pi \varepsilon \rho)$ the church: "I am now rejoicing in my sufferings in your place, ${ }^{3}$ and in my flesh I am

Until 2010, James A. Kelhoffer was Associate Professor of New Testament and Early Christian Literature at Saint Louis University in St. Louis, Missouri. He is now Professor and Chair of New Testament Exegesis at Uppsala University in Sweden. 
completing what remains ${ }^{4}$ of Christ's afflictions for the sake of his body, that is, the church." Even prior to the (deutero-Pauline) author of Colossians, the apostle Paul highlights the value of Christians' readiness to face hardship as an assurance of their eschatological hope: "And if [we are God's] children, then [we are] heirs, heirs of God and joint heirs with Christ-if, in fact ( $\left.\varepsilon^{\prime} i \varepsilon \varepsilon \rho\right)$, we suffer with him, in order that we may also be glorified with him." The dependent clause beginning with عï $\pi \varepsilon \rho$ (Rom 8:17b) emphasizes that future glorification is predicated conditionally upon suffering with Christ in the present. ${ }^{6}$ On this point James D. G. Dunn argues that in Romans 8:17b,

[t]he final force of the iv should not be weakened. The implication is again clear: suffering with Christ is not an optional extra or a decline or lapse from the saving purpose of God. On the contrary, it is a necessary and inescapable part of that purpose. Without it future glory would not be attained...?

According to the soteriology of Romans 8, the several realizations of the Christian experience enumerated in $8: 12-17 \mathrm{a}$-being led by God's Spirit and believers' identity as God's children and as joint heirs with Christ-are by themselves incomplete unless ( $\varepsilon i ̈ \pi \varepsilon \rho)$ one also is prepared to suffer as Christ did. In a different letter, Paul states that the failure of the Thessalonians to endure hardships would have nullified their salvation. ${ }^{8}$

\section{Withstanding Persecution as a Defense of Paul's Apostolic Authority}

In addition to highlighting readiness to withstand hardship as an integral component of the Christian life, Paul calls attention to his suffering as a defense of his apostolic authority. Toward the end of Galatians, Paul highlights both the Galatian agitators' cowardice and his sufferings as "proof" that he should not have to face opposition from these rival Christian missionaries: "It is those who want to make a good showing in the flesh that try to compel you to be circumcised-only lest they be persecuted for the cross of Christ.... From now on, let no one make trouble for me, for I bear in my

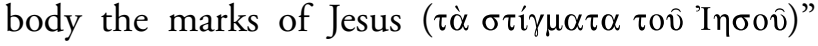
(Gal 6:12, 17; cf. 4:29; 5:11).

Naturally, Paul's Christian opponents would have assessed differently the value of Paul's suffering: although they may have conceded that Paul had faced difficulties, they still would have denied Paul's attempt to transfer the posited value of his sufferings as a corroboration of his status as Christ's aposthe to the Gentiles. When Paul responds to the "super-apostles" in 2 Corinthians 11:23-33, a similar argument of Paul about his sufferings is vulnerable to the same rejoinder. To these examples from the Pauline tradition, numerous others could be added. ${ }^{9}$ In what follows, we consider several additional NT authors who highlight the value of Christians' readiness to face hardship as a corroboration of their faith(fulness).

\section{Peter}

The author of 1 Peter makes the audacious, if not naïve, claim that hostile oppressors will repent if the faithful remain firm and continue to do good until the time of the imminently anticipated parousia. Such hope gives value and purpose to Christians who suffer, which "Peter" leverages to influence their behavior. The author first urges the congregation as a whole to conduct themselves "honorably among the Gentiles, so that, though they malign you as evildoers, they may see some of your good works and glorify God on the day of visitation" (1 Pet 2:11-12).

Next follows an exhortation that Christian slaves must follow Christ's example of readiness to suffer (2:18-25). In the following verse,

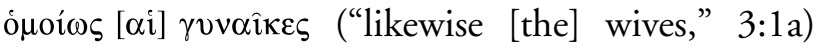
connects the situation of Christian wives to that of the aforementioned enslaved Christians, maintaining that wives must "likewise" be subject even to severe, unbelieving husbands (3:1-6). The hope that, as a result, some outsiders will become Christian is indicated in 1 Peter 3:1 with the author's

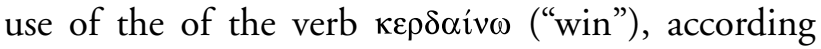
to which some long-suffering wives will "win" their husbands to the faith. ${ }^{10}$ 
These exhortations highlight the acute suffering to which this (pseudonymous) author believes slaves and wives of unbelievers ${ }^{11}$ —indeed, the Christian community as a whole ${ }^{12}$-are called. A potential difficulty is that the author's optimism is futureoriented and offers neither immediate relief to the oppressed nor any limitation to the amount of (domestic) abuse that a slave or wife could be expected to endure for the sake of the gospel.

\section{Hebrews}

Like Paul and the author of 1 Peter, the anonymous author of Hebrews expects that his addressees be prepared to endure hardship for their faith. $\mathrm{He}$ asks that they "recall the earlier days" when, laudably, they endured persecution and, presumably not without risk, visited imprisoned fellow believers (Heb 10:32-34; cf. 11:26; 12:1-4). The author concludes with an exhortation that they voluntarily "go out to [Jesus] outside the camp, bearing his abuse" (Heb 13:13). That is, he implores that they choose to accept some kind of suffering as part of identifying with Jesus' suffering for them. If they will do so, they will receive a confirmation that they are not, as the author fears that some of them are, lapsing into apostasy (see Heb 5:11-6:2; 6:11-12; $10: 25 ; 12: 12)$.

\section{Revelation}

Relative to the other NT writings, the Revelation of John posits a distinctive scenario: the faithful must be prepared to endure the anticipated "great tribulation" (Rev 7:14) in order to be seated with Christ on his throne (Rev 3:21; cf. 7:15; 20:4). Although this "great tribulation" has hardly begun, it soon will become manifest. John's depiction of Antipas, the only Christian whom Revelation reports as having been killed ( $\operatorname{Rev} 2: 13)$, is emblematic of this anticipated tribulation for three reasons.

First, Antipas's stature as Christ's "witness" and "faithful one" (Rev 2:13b) is strikingly similar to that given to Christ, "the faithful witness" (Rev 1:5a). Second, Antipas exemplifies the uncompro- mising resistance that John expects of all the faithful (Rev 2-3, esp. 2:14, 20), whether that resistance be against Jews, polytheists, or "heretical" Christians. Third, John construes the singular event of Antipas's death as foreshadowing an imminent persecution that will produce numerous martyrs and culminate in the judgment of all unbelievers, as well as of some purported Christians, of whose practices John does not approve. ${ }^{13}$

One implication of John's call to resistance and visions of coming persecution is that Revelation's soteriology is to be distinguished from that, for example, in 1 John, which "speaks of Christian victory not as a condition still to be accomplished, but as an act which is already achieved." 14 By contrast, Revelation denies any assurance of salvation in the present; instead, the author stipulates requirements for believers' present and future conduct, including that they remain faithful during the anticipated persecution in order to attain-or, at any rate, retain - a place on Christ's heavenly throne (Rev 3:21).

\section{The Synoptics}

The Synoptic Gospels likewise maintain that authentic discipleship entails not only recognition of Jesus as God's suffering Messiah (for example, Mk 8:31), but also readiness to suffer as Jesus did: "If any [person] want[s] to become my follower[s], let him [or her] deny himself [or herself] and take up his [or her] cross and follow me. [35] For the one who wants to save his [or her] life will lose it, and the one who loses his [or her] life for my sake, and for the sake of the gospel, will save it" (Mk 8:34-35; cf. Mt 16:24\|Lk 9:23). As a partial fulfillment of Mark 8:34-35, Mark highlights Simon of Cyrene's laudatory example of carrying Jesus' cross (15:20b-24; cf. Mt 27:32c\|Lk 23:26). Although Simon's service is not voluntary, the occurrences of aip ("take up") and $\sigma \tau \alpha v \rho o ́ s$ ("cross") in 8:34 and 15:21 make the evangelist's allusion to Jesus' invitation to discipleship in Mark 8:34 unmistakable. ${ }^{15}$ The Lukan parallel to Mark 15:21 accentuates even further the parallelism between Mark 8:34 and 15:21: only 
in Luke 23:26 does Simon carry the cross "after [or: behind, ö $\pi \_\theta \varepsilon v$ ] Jesus." The Lukan embellishment picks up on Mark 8:34a\|Luke 9:23a, where Jesus offers the invitation to follow "after" (ö $\pi$ í $\omega$ ) him (Lk 9:23a).

Although the Pauline letters, 1 Peter, Hebrews, Revelation, and the Synoptics reflect profound differences in genre and theology, they highlight the common theme of suffering as a corroboration of the believer's standing. The same may be said for additional Gospel passages and the Acts of the Apostles. ${ }^{16}$

\section{The Dubious Standing of Persecutors}

Another aspect of persecution as a basis of legitimation is the questioning of the standing of the depicted persecutors, who in the NT are usually Jewish. Already in 1 Thessalonians, Paul calls into question the standing of "the Jews" because of what they did to Jesus, to Jesus' Judean followers, to the Israelite prophets, and to Paul and his companions:

For you, brethren, became imitators of the churches of God in Christ Jesus that are in Judea, for you suffered the same things from your own compatriots as they did from

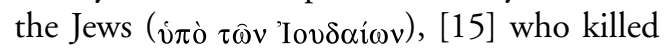
both the Lord Jesus and the prophets, and drove us out; they displease God and oppose everyone [16] by hindering us from speaking to the Gentiles so that they may be saved. Thus they have constantly been filling up the measure of their sins; but God's wrath has overtaken them at last (1 Thess 2:14-16).

Such critiques of Jewish persecutors are much more prominent and developed in Matthew, John, Luke, and especially Acts. The ethical problem posed by such (possibly historicized) depictions of persecutors-namely, whether allegations of persecution can delegitimize an individual's or a group's religious standing-receives attention below. In what follows, we consider examples in Matthew, John, and Luke-Acts.

\section{Matthew}

From the various traditions and redactional tendencies of Matthew, Luke, and John, the intertwined themes of highlighting the oppressed disciples and critiquing the depicted persecutors' standing come to the fore. That is to say, persecution works both positively and negatively vis-à-vis questions of legitimacy: the primary difference lies between Jesus' mistreated disciples and their (usually) Jewish persecutors. The Gospel of Matthew exemplifies this problem in its progressive revelation of the purported persecutors' identity. Initially in Matthew, the persecutors are presumably Jews who oppose the "righteousness" of Jesus' followers (Mt 5:10-12). In the Matthean mission discourse, those who will persecute the apostles are clearly Jewish, since the Twelve are sent only to Israelites (Mt 10:5-6). ${ }^{17}$ Later, the Matthean Jesus addresses to "the chief priests and the Pharisees" the Parable of the Wedding Celebration (22:2-14), which highlights the suffering of missionaries from the Matthean community. ${ }^{18}$ Moreover, at Matthew 23:34 it is the scribes and Pharisees who will "whip" ( $\mu \alpha \sigma \tau$ เүó $\omega)$ and even "crucify" ( $\sigma \tau \alpha v \rho o ́ \omega)$ some of Jesus' followers.

Strikingly, Matthew extends the guilt imputed to these scribes and Pharisees to additional Jews, who are depicted as "this generation" (Mt 23:36), and to the city of Jerusalem, whose "house" will be left desolate (23:37-28). Finally, the Matthean eschatological discourse predicts that "all nations" will hate and persecute Jesus' followers, apparently while the Matthean community conducts missionary work among the Gentiles (Mt 24:9-14).

\section{John}

The Gospel of John questions the $\lambda \alpha \tau \rho \varepsilon i \alpha$ ("worship" or "service" [i.e., to God]) of Jewish persecutors who will kill some of Jesus' followers. ${ }^{19}$ What the persecutors construe as "service" to God by killing Jesus' followers confirms that the oppressors belong to the world (cf. Jn 15:19) and that they do not understand the $\lambda \alpha \tau \rho \varepsilon i \alpha$ that God 
truly desires. Thus, like Matthew (and Luke-Acts), the fourth Gospel couples allegations of persecution with questions of legitimacy. This legitimacy pertains to the validity of Jesus' followers, who are excluded from the synagogue (Jn 16:1; cf. 9:22; $12: 42$ ), and questions the standing of their potentially violent oppressors.

\section{Luke-Acts}

This brief overview of withstanding persecution as a source of legitimacy in the NT concludes with Luke-Acts, and concurs with Scott Cunningham's thesis that Luke's Gospel foreshadows instances of persecution narrated in greater detail in Acts. ${ }^{20} \mathrm{~A}$ prominent emphasis in Acts is to question, confirm, and derive legitimacy because of persecution.

First, Luke questions the legitimacy of the depicted persecutors, who are usually Jewish. ${ }^{21}$ Second, he confirms the standing of persecuted Christians, whether the apostles, Stephen, or, above all, Paul, the persecuted former persecutor. ${ }^{22}$ As a corollary, Luke's progressive disclosure of the extent of Paul's previous persecutions of the church-saving the more violent depictions for Acts 22:4 and 26:9-11 rather than placing them at Paul's initial introduction (at 8:3 or 9:1-2) -is consistent with an agenda of presenting Paul as a sympathetic character who suffered unjustly in Acts 9-21 (or 9-25). By contrast, a revelation like Acts $26: 10-11,{ }^{23}$ if disclosed already in Acts 8-9, would have made it clear from the beginning of Paul's missionary work that the Jews merely wished to do to Paul what Paul had earlier been doing to Jesus' followers in Jerusalem, Judea, and any number of other places.

Third, one may plausibly infer that, in addition to questioning the depicted persecutors' legitimacy and confirming the standing of earlier persecuted followers of "the Way," Luke derives legitimacy for his later Christian constituency because of those who in the past have suffered, corroborating the standing of later Gentile Christians who may still experience conflict or oppression, whether from Jews or others. The principle of transference may be operative in Acts, such that past persecutions, which do not presently impact (later) Lukan communities, may offer a precedent for corroborating the standing of contemporary Gentile Christians. Whenever later Christians should face persecution, whether from Jews or Gentiles, they can claim to stand in the legacy of the suffering apostles, Stephen, and Paul.

These observations support the argument that corroboration stemming from persecution plays a prominent and heretofore under-appreciated role in NT constructions of legitimacy. This conclusion about persecution as a source of validation in the NT literature gives rise to an ethical and hermeneutical quandary that the remainder of this article addresses.

\section{The Resulting Ethical and Hermeneutical Quandary}

We have seen how the NT authors present their various valuations of Christians' suffering as a basis of legitimation as if they were self-evident. Moreover, these authors do not acknowledge the possibility of competing interpretations, or that oppressed Christians someday could become oppressors. This section considers the hermeneutical and ethical dilemma that reflecting on suffering is never "value neutral," and that even those who have truly suffered bear a responsibility not to follow their oppressors in oppressing others. The problem comprises four interrelated points:

1. In an ancient or a modern context, reflecting on suffering is never "value neutral." Neither are assertions about suffering's value for the corroboration of a person's or a group's standing or legitimacy ever self-evident. On the contrary, such assertions are built upon numerous presuppositions and, as such, are subject to redefinition or even rejoinder from others. Therefore, even if those concerned agree generally about "what happened" (for example, a persecution or its extent), one could, hypothetically, appeal in many different ways to persecution as a basis for corroborating standing or authority.

2. The NT authors assume that their various valuations of Christians' suffering are self-evident. 
None of these authors acknowledges the possibility of other perspectives (whether actual or hypothetical) from Jews, polytheists, or other Christians.

3. Even those who truly have suffered bear a responsibility not to follow their oppressors in oppressing others.

4. The NT authors reflect no concern that oppressed Christians could someday, mutatis mutandis, play the role of oppressors.

The first and third points are prolegomena that, I trust, would be accepted by ethicists of any number of modern religious traditions, Christian or otherwise. ${ }^{24}$ The preceding overview of select NT passages substantiates the second point.

Like the second point, the fourth point follows from the preceding discussion and introduces a problem of ethics and theological method: the literature that eventually came to be recognized as the NT devotes considerable attention to the suffering of Jesus and of Jesus' followers, but reflects essentially no concern for the suffering of other people. Historians of religion and responsible Christian interpreters of biblical literature therefore must recognize that the earliest Christian tradition bequeaths to us an interpretive quandary that it does not even acknowledge, much less attempt to address: Who assigns value to human suffering, and on what grounds? And under what circumstances could suffering amidst persecution become a valid ground for legitimation? The final pages of this article sketch out possible approaches to this problem.

\section{The Hermeneutical Fallacy of Positivistic, Binary Readings}

In an important essay, Shelly Matthews calls attention to depictions of "the Jew as Violent Other in ancient and modern historiography." 25 She observes that although much sophisticated scholarship has addressed NT accusations against Jews for killing Jesus, there has not been an effort to assess "the numerous New Testament depictions of Jews as agents of violence" against members of the early Jesus movement(s) "subsequent to the crucifixion." 26 Matthews critiques two deficiencies in much previous scholarship: (1) reading the NT allegations "positivistically" as unbiased historical evidence; and (2) characterizing the persecutors as "Jews," and characterizing those persecuted as "Christians"that is, as two distinct groups. ${ }^{27}$

Taking the Gospel of Matthew as a test case, she does not deny that Matthew could offer evidence of violence by Jews against Jesus' followers but rightly insists "that reconstructions of Matthean history need to be made on the basis of theoretical models, rather than proof-texts." 28 Whereas some recent scholars prefer to speak of "intra-Jewish violence," 29 Matthews suggests a different way forward: she derives from the Jewish historian Josephus's account of the death of the apostle James an alternate way of construing accusations of persecution in the Gospel of Matthew. ${ }^{30}$ Although her use of Josephus is not without difficulties, ${ }^{31}$ on a historical level Matthews makes a plausible argument.

For the modern interpreter, the problem remains that, in the depictions of Matthew and several other NT authors, "the binary (Jewish) persecutors/(Christian) persecuted" 32 plays a prominent role in both corroborating and questioning legitimacy. Accordingly, Matthews calls attention to an important interpretive and ethical dilemma, namely that whereas the NT authors oftentimes resort to "binary" constructions of the "persecutors" and the "persecuted," 33 the historical reality may well have been significantly more complex. When the NT texts corroborate arguments about legitimacy on instances of persecution, the implications of the problem are even more far-reaching. This problem becomes exponentially more complex whenever modern religious groups-whether Jewish, Christian, Muslim, or others-cite ancient allegations of persecution as a basis for contemporary constructions of legitimacy.

Matthews also calls attention to another problem, albeit only in passing: "The critiques of how... [the] privileging of suffering has been used to justify complacency in the face of oppression are multiple and crucial." 34 At this point it must be recognized that our discussion has left the "original context(s)" of the NT authors: we are now considering the possibly unintended consequences of the later reception of the NT. Yet inasmuch as the church bears responsibility for its interpretation of 
Scripture, the question may-and, indeed, needs to-be asked: have the posited benefits of deriving legitimacy from hardships and persecutions made the church less prone to speak out against evil and injustice? This is precisely the argument of Anthony B. Pinn, to whose study of suffering and evil in North American Black theology Matthews refers. ${ }^{35}$ The question deserves to be asked for any number of Christian (and other religious) traditions, both ancient and modern. The present article cannot offer a definitive answer to such a complex hermeneutical problem. A final section considers how several models for approaching NT ethics could provide a way forward.

\section{Models of New Testament Ethics}

In a recent monograph Brian Brock discusses five models for approaching NT ethics, as reflected by leading ethicists and NT scholars: ${ }^{36}$

1. Reading Self-Consciously: The Hermeneutical Solution (E. Schüssler Fiorenza, D. Patte, C. Cosgrove)

2. Reading Together: The Communitarian Solution (B. Birch and L. Rasmussen, S. Fowl and L. G. Jones)

3. Focused Reading: The Biblical Ethics Solution (F. Matera, R. Hays, J. H. Yoder)

4. Reading Doctrinally: The Biblical Theology Solution (B. Childs, F. Watson, J. Webster)

5. Reading as Meditation: The Exegetical Theology Solution (proposed by Brock himself and based in part on D. Bonhoeffer)

Of course, one cannot predict a priori how a particular ethicist or approach to ethics will answer a certain problem. Nevertheless, for heuristic purposes Brock's discussion of five different models is helpful for considering how these models could be used to address the hermeneutical and ethical quandary resulting from deriving legitimacy from withstanding persecution.

\section{Reading Self-Consciously}

The first approach Brock discusses, modeled by Elizabeth Schüssler Fiorenza et al., calls for self- conscious hermeneutics in response to oppressive traditions and interpretations. ${ }^{37}$ Indebted to this approach, the present article recognizes that any assertion of authority, legitimacy, or standingincluding assertions claimed on the basis of withstanding persecution-is a claim to power; as such, it has the potential to exclude and even oppress other people, authorities, or religious traditions. It is not my purpose, however, to argue that any assertion of legitimacy is de facto oppressive. Nor do I wish to suggest that all such claims are morally suspect.

Above all, self-conscious hermeneutics make plain two needed points of caution. First, it would be naïve, and possibly dangerous, to ignore the possibility that constructions of who the "persecutors" and the "persecuted" are could sanction oppression of others. Second, one also must be cautious, lest a self-conscious hermeneutic touting liberation itself could become a source of oppression. ${ }^{38}$

\section{Reading Together}

Brock next considers the approach of "Communitarians," who urge that we read Scripture together-not individually or, even worse, individualistically. ${ }^{39}$ Communitarians such as Bruce Birch and Larry Rasmussen affirm that the diversity in Scripture offers an impetus for embracing diversity in the church today. For the present inquiry, this approach offers the advantage of not restricting the valuations of suffering to a single ancient or modern authority.

A lacuna in the discussion, however, is how to define the community with which "we" read. I concur with Francis Watson, who critiques those who would cloister the Christian narrative within inter-systematic truths without accountability to the larger world. ${ }^{40}$ Our hermeneutics must be accountable to not only Scripture but also to the impact they have had-or plausibly could have-on others. What is necessary, then, is not only to interpret together accounts of suffering, as the Communitarians would urge, but also to transcend a dichotomy of "us" versus "them." Indeed, such dichotomies can spawn both arguments for legitimation and schisms within religious, ethnic, political, and other 
systems. Furthermore, positivistic, binary readings of Scripture are particularly problematic when an individual or community differentiates "us" from "them," searching for salvation-historical archetypes that legitimize "us" and delegitimize our foes. ${ }^{41}$

While recognizing the benefits of reading Scripture in community, I would like to suggest a somewhat more ambitious way of moving forward: $\mathrm{em}$ bracing dialogue about suffering and persecution not only within one's community but also between distinct, overlapping, or even competing communities or constituencies. This would entail, at the very least, that one community recognize the suffering of another community.

I mention briefly three examples. First, one wonders how Protestant-Catholic relations in sixteenthcentury England might have developed if Catholics had recognized the unjust exile, imprisonment, and execution of hundreds of Protestants under Mary Tudor (Queen Mary I, 1553-58), and if Protestants had recognized similar oppression of Catholic martyrs already under Henry VIII (d. 1547). A prerequisite for such a dialogue would be setting aside the divisive agendas of both John Foxe's (in)famous Book of Martyrs (2 ${ }^{\text {nd }}$ English edition, 1583), and of Foxe's most vehement Catholic critics. ${ }^{42}$

Second, an essential starting point for contemporary Jewish-Christian dialogue is that Christians recognize the systematic oppression and murder of millions of Jews and others in the Shoah, or Holocaust, which had roots in centuries of Christian anti-Jewish propaganda and oppression. Moreover, Christians who construe the Jews' suffering as divine vengeance or retribution in the first or the twentieth centuries (or any point in between) naturally stifle possibilities of dialogue and reconciliation.

Third, in the ongoing Israeli-Palestinian conflict, there is clearly a need to transcend the prevalent discourse, in which each side trumpets its own narrative(s) of unjust suffering at the expense of the other group's legitimacy. What would be possible if the leadership on both sides were to recognize that those they represent have indeed mistreated and unnecessarily caused suffering for the other constituency? The possibilities are many, if we will reach out with compassion toward others' suffering, rather than forging our suffering into a weapon for attacking others.

\section{Focused Reading}

The third approach Brock discusses is that of biblical ethicists, such as Frank Matera, Richard Hays, and John Howard Yoder, who, generally speaking, construe diversity in Scripture as a problem that must be acknowledged and, to the extent possible, be overcome en route to synthesizing biblical teachings for application to current ecclesial situations. ${ }^{43}$ A welcome implication of this approach would recognize the great diversity of ways of talking about persecution that are already reflected in the NT. Although principles of valuation and transference for the purpose of legitimation pervade much of the NT, the variety of situations addressed, persecutors depicted, and future scenarios anticipated must also be acknowledged. Accordingly, exegetes and ethicists must recognize that the NT does not offer a single "biblical" way of construing persecution as a corroboration of standing. Any approach to the hermeneutical dilemma has to confess that the diversity in Scripture is itself part of the problem.

\section{Reading Doctrinally}

Another approach to the NT and ethics is the biblical theology solution, indebted to the theological exegesis of Karl Barth and Hans Frei, and reflected by Brevard Childs, Francis Watson, and Stephen Webster. ${ }^{44}$ The idea here is that God's redemptive work with humanity offers a context for interpreting Scripture and addressing questions of ethics. This model for reflecting theologically and ethically on persecution would offer the opportunity to consider the church's hardships as part of God's continuing work of redemption: just as characters in Scripture-above all, Jesus-suffered oppression and even death, so can the people of God face analogous hardships and find hope in God's eschatological redemption. Such reflection can also offer comfort to oppressed individuals and communities, encouraging them to remain steadfast in their witness to the good news. 
A potential difficulty stems from the fact that, as noted above, the value of withstanding persecution is not self-evident but is predicated upon numerous other conclusions. ${ }^{45}$ By positing the redemptive history reflected in Scripture and interpreted within a particular theological tradition ${ }^{46}$ as a context for interpreting experiences of persecution, one would add yet another possibly disputable variable to an already complex equation. Additional attention, then, would need to be given to the following questions: which conception of God's redemptive work shall be used for interpreting later persecutions; and for which of the various contemporary ecclesial contexts (including southern hemispheric ones) would a particular interpretation be apt?

\section{Reading as Meditation}

Brock presents his own proposal as "the Exegetical Theology Solution" and bases it in part on Dietrich Bonhoeffer's approach to Scripture. ${ }^{47}$ Brock agrees with Francis Watson that interpretation(s) of the Christian narrative must be accountable to both Scripture and the larger world. ${ }^{48}$ Brock also critiques Watson for (allegedly) presenting moral reflection as purely rational; for Brock, moral reflection also needs an affective dimension. ${ }^{49}$ Brock's search for an affective, or experiential, component to ethics is exemplified in his question, "How does Scripture conceive of itself as shaping Christian prayer, repentance, and transformed behavior?" ${ }^{50}$ As examples of "encountering the ethos of Scripture," Brock reviews Augustine and Luther's interpretations of the Psalms. ${ }^{51} \mathrm{He}$ then implores that other believers join him in "singing the ethos of God" through practicing "ethical exegesis." 52

One can commend Brock's exhortation to move beyond purely rational ethical reflection and to consider how the affective experiences of prayer, meditation, worship, and praise can help people internalize ethical ideas and practices. It is also laudable to ask how "transformed behavior," or "good works," will be "the craftwork of exegetical judgment." 53 Yet I would not be the first critic of Brock to note that his proposal is both quite vague and largely lacking in concrete suggestions for liturgical or practical application. ${ }^{54}$ Brock perhaps would have done well to acknowledge Albert Schweitzer as a distinguished precedent for transcending the rational limits of ethical reflection and affirming the necessity of mysticism as a precursor to the formation of ethical behavior. ${ }^{55}$ For Schweitzer, "ethical mysticism" leads not to denial of the world but, rather, to accountability not only to all people but also to the entire creation. ${ }^{56}$ More recently Karl Rahner, whom Brock also does not cite, highlighted the importance of mysticism in Christian experience and formation. ${ }^{57}$

Early Christian tradition also offers three points that could advance Brock's inviting, if opaquely formulated, proposal. First, when the apostle Paul speaks of imitating himself, Christ, and other saints who persevere under persecution, ${ }^{58}$ these (and other) examples can continue to inspire steadfastness amidst oppression and injustice today. Likewise, the author of Hebrews refers to "a cloud of witnesses" who, along with Jesus, implore the faithful to "run with perseverance" (Heb 12:1). A third point comes from the Syriac preface to Eusebius of Caesarea's Martyrs of Palestine, which states that "we... need the help of [the martyrs'] prayers," and exhorts, "let us also communicate with them... and let us make their wondrous excellence a lasting vision before our eyes." ${ }^{\prime 59}$ For these three early Christian witnesses, one does not "run" alone but with appreciation for, and even assistance from, the people of God both past and present.

Additionally, it would be desirable to see not only attitudes but also actions transformed through reflection-or meditation-on the ethics of deriving legitimacy from enduring persecution. In much of the church today, it could reflect progress, for example, to refrain from prejudicial statements or discriminatory acts against construed oppressors. It would be an even greater advance to see people from distinct faith traditions coming together to reflect, and even pray, about this challenging issue. The question I would like to see ethicists and other constructive theologians tackle is as follows: How can a faith community reflect on hardship and persecution without dehumanizing the persecutor as "other" and therefore undeserving of love, respect, or even forgiveness? 


\section{Persecution: Impediment or Catalyst for Reconciliation?}

We have considered five approaches to NT ethics, which Brian Brock dubs the hermeneutical, communitarian, biblical ethics, biblical theology, and exegetical theology solutions. I suggested that each of these approaches imparts both limitations and potential for addressing the ethical and hermeneutical dilemma posed by deriving legitimacy from religious persecution. Inasmuch as assertions of legitimacy or standing are claims to power and can exclude other people, the Christian tradition has not only a calling but also a duty to examine the basis of any such assertions, including those assertions predicated upon withstanding persecution. However much we may value our suffering or that of other saints with whom we identify, it deserves to be asked whether it is truly worthwhile to forge, or foster, divisions within religious traditions, and even humanity, on this basis.

In terms of the philosophy of religion, one may ask which comes first-an experience of persecution, or the concept of salvation history (or salvation mythology ${ }^{60}$ ) that it legitimates? The question is equally pertinent for the apostle Paul, St. Augustine, al-Qaeda, and their opponents/enemies, however construed. Perhaps one might posit a complementary development of constructions of legitimacy based on persecution, on the one hand, and of salvation history/mythology, on the other hand: a concept of "persecution" assumes an understanding of who "we" are and of some shared history/mythology. The endurance of persecution can become part of a group's collective memory, reinforcing an identity derived from oppression, whether directed against our predecessors or us. One contribution of this article is to highlight the role that ascribing value to suffering and transferring that value for the purpose of legitimation can play in the formation of religious identity, including identity derived from salvation history/mythology. It should also give us pause that, once a past persecution becomes embedded within salvation history/mythology, it can, alternately, continue to inspire or to delegitimize, respectively, the faithful and their perceived oppressors.

Moreover, one cannot agree with Bart D. Ehrman that "the Bible fails to answer our most important question-why we suffer." 61 This article demonstrates that the NT literature hardly fails to answer this question. Answers are indeed given-albeit answers that bequeath an ethical and hermeneutical quandary to subsequent interpreters. I submit that deriving legitimacy from persecution presents a quandary not unlike those inherited from biblical passages that condone slavery or unhealthy attitudes toward women (and men). Thankfully, there are virtuous, healing, and life-giving ways of speaking about one's suffering without grounding one's standing in oppression(s) past or present, let alone demonizing one's opponents in the process. Whereas the absence of such reflection poses an impediment to reconciliation, the cultivation of such reflection yields a catalyst for healing and forgiveness.

Critical, careful, and even prayerful reflection on how we construe ourselves in relation to suffering is an agendum inadequately realized in the NT that commends itself for twenty-first century ethics and theology. I make no pretension that an exegetical analysis of the NT could, by itself, solve this problem for contemporary Christian or other religious communities. If experts in other areas of theological and religious studies will add to the conversation, there will be potential for more nuanced reflection and dialogue. The present inquiry will have served its purpose if it better defines the task and ethical responsibility of analyzing both how Scripture, and we today, talk about persecution as a basis of legitimation, and how it might lead to further critical reflection, discussion, and even reconciliation.

\section{Endnotes}

1. Question posed to, and answered by, Roger Louis SchützMarsauche (a.k.a. Brother Roger [Frère Roger]), apud Kathryn Spink, $A$ Universal Heart: The Life and Vision of Brother Roger of Taizé (1986, reprint London: Society for Promoting Christian Knowledge, 2005), 175.

2. On this point I follow Michael Wolter, "Der Apostel und seine Gemeinden als Teilhaber am Leidensgeschick Jesu Christi: 
Beobachtungen zur paulinischen Leidenstheologie," New Testament Studies 36 (1990): 535-57 at 537.

3. The translations "for your sake" and "instead of you" for vi $\pi \dot{\varepsilon} \rho$ ím are also possible.

4. See Andrew T. Lincoln and Alexander J. M. Wedderburn, The Theology of the Later Pauline Letters (Cambridge: Cambridge University, 1993), 38: "By opting for 'what remains' rather than 'what is lacking' as a translation of $\tau \dot{\alpha} \dot{v} \sigma \tau \varepsilon p \eta \dot{\mu} \mu \alpha \tau$ one at least mitigates one problem, the possible implication that somehow Christ's suffering had been deficient or insufficient."

5. See further Barnabas M. Ahern, "Fellowship of His Sufferings," Catholic Biblical Quarterly 22 (1960): 1-32 at 18: "Here he [Paul] merely repeats what he has developed in Romans 6:3-12ff:: Christians, because they are incorporated into the body of Christ, share not only his life but also his death." Ahern's observation of continuity with Romans 6 has some merit but overlooks the conditionality of eil $\pi \varepsilon \rho$ in Romans 8:17b.

6. With J. D. G. Dunn, Romans, vol. 38A and B in Word Biblical Commentary (Dallas: Word, 1988), 1:456 (on Rom 8:17): "a distinction

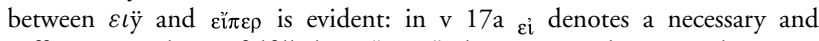
sufficient condition fulfilled = "since"; but [in 8:17b] عï $\pi \varepsilon \rho$ denotes a condition not yet fulfilled and therefore a consequence dependent on the fulfillment of the condition ..."

7. Dunn, Romans, 1:456 (on Rom 8:17, emphasis added).

8. See 1 Thess 3:1-5, where Paul discloses his earlier fear for the Thessalonians "that somehow the tempter had tempted you and that our

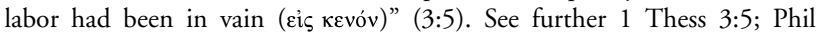
$1: 28-30 ; 3: 8 b-9$.

9. E.g., 1 Thess 1:6; 2:14-16, 17-18; 1 Cor 12:26; Rom 5:2-5; 2 Thess $1: 4-5 ; 2$ Tim 1:8-12; 2:8-13; 3:10-12; 4:1-5.

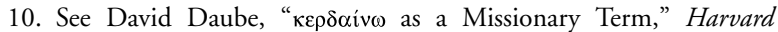
Theological Review 40 (1947): 109-20.

11. See David L. Balch, Let Wives Be Submissive: The Domestic Code in 1 Peter, vol. 26 in Society of Biblical Literature Monograph Series (Chico, Calif.: Scholars Press, 1981), 82-105.

12. With J. Ramsay Michaels, 1 Peter, vol. 49 in Word Biblical Commentary (Waco: Word, 1988), 152 (on 2:18-25): "the appeal to Christ as the example to those so mistreated is central to the argument of the epistle as a whole (cf. 3:18-4:1), and it is scarcely plausible that Peter introduced it solely to encourage... household servants. Because he writes to all as 'God's slaves' (2:16), the servants... can be effectively used as stand-ins for all Christian believers ..."

13. Rev 6:9-11. See further $\operatorname{Rev} 7: 9-15,17 ; 8: 3-5 ; 9: 20-21$; $11: 1-13 ; 13: 7-10 ; 14: 4-5,12 ; 15: 2-4 ; 17: 14 ; 19: 7-8 ; 20: 4-6,11-15$; $21: 4,8 ; 22: 10-12,15$.

14. Elisabeth Schüssler Fiorenza, Revelation: Vision of a Just World, 2nd ed. (Minneapolis: Fortress, 1991), 48 (emphasis added); cf. Rev 12:11; 1

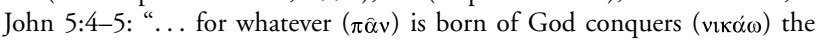

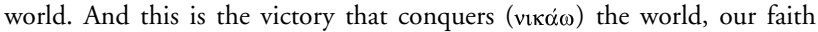

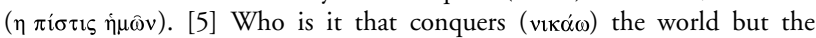

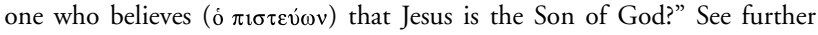
1 John 2:13; 4:4.

15. So also Joachim Gnilka, Das Evangelium nach Markus, 4th ed., vol. 2 in Evangelisch-katholischer Kommentar zum Neuen Testament (NeukirchenVluyn: Neukirchener, 1994), 2:315 (on Mk 15:20b-21); R. T. France, The Gospel of Mark: A Commentary on the Greek Text (Grand Rapids: Eerdmans/Carlisle: Paternoster, 2002), 641 (on Mk 15:21); Robert H. Gundry, Mark: A Commentary on His Apology for the Cross (Grand Rapids: Eerdmans, 1993), 944.

16. E.g., Q/Luke 6:22-23, 26\|Mt 5:11-12; Q/Luke 11:47-51\|Mt 23:29-36; Mt 10:17-22a; 13:20-21; 16:24; 19:28-30; 23:34-38; $24: 9-14 ; 26: 6-13 ; 27: 32 c$, 54; Lk 8:13; 9:23; 18:28-30; 21:12-19;
23:26, 48-49; 23:48a; Acts 5:33, 40-41; 7:55-56; 9:16; 14:19, 22; $20: 22-23 ; 21: 4,11 ; 21: 26-27 ; 25: 19,25 ; 26: 31-32$; Jn 15:18, 20; 16:1-2 (cf. 9:22; 12:42b-43).

17. Mt 10:17-22a. The contrast between the perilous Matthean mission discourse and those in Mark and Q, which do not mention persecution or violence against the disciples (Mark 6:6b-13\|Luke 9:1-6; Q/Luke $10: 1-24)$, is therefore noteworthy.

18. Mt 21:45; cf. 22:1. Only in the Matthean version of this parable is there mention of violence, death, and persecution (22:6), as well as the subsequent destruction of the aggressors' "city" (22:7).

19. John 16:2: "They will put you out of the synagogues. But an hour is coming when everyone who kills you will think he is offering a service [or: worship; Gk.: $\lambda \alpha \tau$ cía] to God." See further John 15:18, 20; cf. 9:22; 12:42b-43; 16:20-24.

20. Scott Cunningham, 'Through Many Tribulations': The Theology of Persecution in Luke-Acts (Sheffield: Sheffield Academic, 1997), 42; see Q/Luke 6:22-23; Luke 7:36-50; 8:13; 9:23, 49-50; Q/Luke 11:49-51; Luke 13:31-32; 21:12-19; 22:28; 23:47, 49.

21. Jewish opposition to the Jesus movement, and especially to Paul, constitutes a major theme in Acts. See Acts 3:14-17; 4:25-26; 5:29; 7:51-53; 9:23-24, 29-30; 12:3, 11; 13:41-52; 14:5-6, 19; 17:5-7; 20:3; $21: 26-27 ; 23: 12-16 ; 24: 5 ; 25: 3,24-25$. An exception to this general pattern is Luke's depiction of the Jews in Beroea, who either receive Paul and Silas's message or at least do not oppose it. Luke presents these

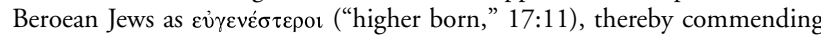
a small, elite portion of Jews and implicitly criticizing the majority of Jews.

22. The basso continuo in these Lukan characterizations of Paul and others is that perseverance in suffering and courage to face (possible) death are markers of Jesus' faithful followers. See Acts 5:33, 40-41; 7:55-56; $9: 16 ; 14: 19,22 ; 20: 22-23 ; 21: 4,11,26-27 ; 25: 19,25 ; 26: 31-32$. Notably, Luke never depicts persecuted Christians who commit apostasy, although Acts 20:29-30 warns of difficulties from both inside and outside the church.

23. Acts 26:10-11: "I not only locked up many of the saints in prison but also cast my vote against them when they were being con-

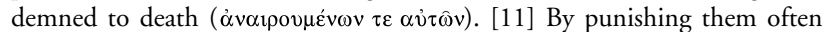
in all the synagogues I tried to force them to blaspheme; and since I was so furiously enraged at them, I pursued them even to foreign cities."

24. I.e., no religious system should be(come) a force of oppression, exploitation, or injustice. Moreover, faithfulness to one's religious tradition includes critiquing both past and present manifestations of that tradition.

25. Shelly Matthews, "Ethical Issues in Reconstructing Intrareligious Violence in Antiquity: The Gospel of Matthew as a Test Case," in Walk in the Ways of Wisdom: Essays in Honor of Elisabeth Schüssler Fiorenza, ed. S. Matthews et al. (Harrisburg, Penna.: Trinity Press International, 2003), $334-50$ at 336.

\section{Ibid.}

27. Matthews, "Reconstructing Intrareligious Violence," 338-40 at 338. Concerning the former shortcoming, Matthews argues, "This positivistic framework leads to an interpretive process akin to fundamentalist prooftexting" (346-47 at 346, criticizing studies by Jack T. Sanders, Graham Stanton, and Ulrich Luz). An example of such positivist prooftexting may also be found in Douglas R. A. Hare, The Theme of Jewish Persecution of Christians in the Gospel According to St. Matthew, vol. 6 in Society for New Testament Studies Monograph Series (Cambridge: Cambridge University, 1967), 126 (cf. 129), who argues that since the witness of Matthew is corroborated by the Paul of Acts (!), there is no reason to doubt Matthew's depictions of the persecutors and the persecuted.

28. Matthews, "Reconstructing Intrareligious Violence," 347. She further argues that "in order to be ethically responsible, such arguments 
would need to avoid the dualistic inscription: Jewish/persecutor and Christian/persecuted" (347-48).

29. Matthews, "Reconstructing Intrareligious Violence," 348, emphasis original, referring to D. J. Harrington, The Gospel of Matthew, Sacra Pagina vol. 1 (Collegeville, Minn.: Liturgical Press, 1991), 147-48 and David C. Sim, The Gospel of Matthew and Christian Judaism: The History and Social Setting of the Matthean Community (Edinburgh: Clark, 1998), 151-63.

30. Matthews, "Reconstructing Intrareligious Violence," 348-49. According to Matthews (p. 350), Josephus "does not inscribe the binary (Jewish) persecutors/(Christian) persecuted, nor even the triangle JewChristian-Roman. Rather, [Josephus] depicts (1) a Jewish high priest hostile to (2) the brother James, who is executed, and (3) certain others (perhaps non-Christian Jews), also executed; (4) a prominent non-Christian Jewish group sympathetic to and politically motivated on behalf of the executed; (5) the Jewish client king; and (6) the Roman overlord." Matthews concludes: "At the very least, the multiple subjects in this text should prevent interpreters from citing it as an instance of Jews responsible for the death of Christians" (p. 350).

31. For example, Matthews's point, that the "prominent nonChristian Jewish group sympathetic to and politically motivated on behalf of the executed" was not "motivated" enough to prevent James's execution ("Reconstructing Intrareligious Violence," 350), would support only the (uncontroversial) claim that not all Jews wanted James to be killed.

32. Cf. Matthews, "Reconstructing Intrareligious Violence," 350, cited in context in the previous note.

\section{Ibid.}

34. Ibid., 344.

35. See A. Pinn, Why Lord? Suffering and Evil in Black Theology (New York: Continuum, 1995); cf. Matthews, "Reconstructing Intrareligious Violence," 344 n. 28.

36. Brian Brock, Singing the Ethos of God: On the Place of Christian Ethics in Scripture (Grand Rapids: Eerdmans, 2007), 3-18. I am grateful to René Such Schreiner for suggestions and feedback on this subsection, as well as for sharing with me portions of her current dissertation research on models of approaching NT ethics.

37. Ibid.

38. Ibid., 16.

39. Ibid., 19-34.

40. Francis Watson, Text, Church and World: Biblical Interpretation in Theological Perspective (Grand Rapids: Eerdmans, 1994), esp. 30-45, 60-77.

41. See Matthews, "Reconstructing Intrareligious Violence."

42. See further on John Foxe's Acts and Monuments (a.k.a. Book of Martyrs), e.g., William Haller, Foxe's Book of Martyrs and the Elect Nation (London: J. Cape, 1963) [ = The Elect Nation: The Meaning and Relevance of Foxe's Book of Martyrs (New York: Harper \& Row, 1963)], 121-22; Alec Ryrie, "The Unsteady Beginnings of English Protestant Martyrology," in John Foxe: An Historical Perspective, ed. David M. Loades (Brookfield, VT: Ashgate, 1999), esp. 53-57; Eamon Duffy, Fires of Faith: Catholic England Under Mary Tudor (New Haven: Yale University, 2009), 39-40, 43-45.

43. Brock, Place of Christian Ethics in Scripture, 35-51.

44. Ibid., 52-70.

45. Another difficulty is that theological dogma, like certain biblical passages, can foster the cause of suppression.

46. See further below on salvation history/salvation mythology.

47. Brock, Place of Christian Ethics in Scripture, 71-95; on D. Bonhoeffer's approach to Scripture, 89-93.
48. Ibid., 61-62.

49. Ibid., 68-70.

50. Ibid., 95 .

51. Ibid., $97-237$ at 97 .

52. Ibid., 239-363 at 239 and 241 .

53. Ibid., 95, 257.

54. Especially Jan G. van der Watt, review of Brock in Review of Biblical Literature 10 (June, 2008): 4, accessed June 16, 2010, http://www.bookreviews.org: “... in the end I was left with a measure of vagueness instead of clarity. To my mind, this is a major problem with the latter part of the book. It borders on a 'play with words.' The result is, of course, that it sounds nice but it is so vague that it leaves the reader unsure of what is expected or suggested." See also Mark W. Elliott, review of Brock in Catholic Biblical Quarterly 70 (2008): 562-64 at 563-64; Peter S. Perry, review of Brock in Currents in Theology and Mission 36 (2009): 212.

55. See Erich Gräßer, "Mystikund Ethik: Ihr Zusammenhang im Denken Albert Schweitzers," in Albert Schweitzer heute: Brennpunkte seines Denkens, ed. Claus Günzler et al. (Tübingen: Katzmann, 1990), 190-95; James Bentley, Albert Schweitzer: The Enigma (New York: HarperCollins, 1992), 132-47, esp. 133-34, 138; cf. Karl Dienst, "Mystik im Protestantismus," Journal of Religious Culture/Journal für Religionskultur 37 (2000): 1-13 at 3 .

56. Schweitzer writes, for example, "Die Mystik... ist nicht die Blume, sondern nur der Kelch einer Blume. Die Blume ist die Ethik" (Schweitzer, Kultur und Ethik [GW II:372], apud Gräßer, "Mystik und Ethik," 192) and "Die das Denken befriedigende Ethik muß aus Mystik geboren werden" (Schweitzer, Kultur und Ethik [GW II:370], apud Gräßer, "Mystik und Ethik," 192).

57. For example, K. Rahner, "The Spirituality of the Church of the Future," in idem, Theological Investigations (23 vols.; trans. Cornelius Ernst; Baltimore: Helicon, 1961-92), 20:143-53 at 149 writes, "[T]he Christian of the future will be a mystic or... will not exist at all... [B]y mysticism we mean.... a genuine experience of God emerging from the very heart of our existence....[T] he ultimate conviction and decision of faith comes...from the experience of God...bursting out of the very heart of human existence. ..." See further Harvey D. Egan, Karl Rahner: The Mystic of Everyday Life (New York: Crossroad, 1998), esp. $55-79$.

58. See 1 Thess 1:6; 2:14; 2 Cor 1:6-7; Phil 1:12-14.

59. See Euseb., Mart. Pal. (L), Praef 2; ET: H. J. Lawlor and J. E. Leonard Oulton, The Ecclesiastical History and the Martyrs of Palestine (New York: Macmillan, 1927-28), 1:329, 11. 1, 3-4, 13-14.

60. On this problem, see, e.g., Heil und Geschichte: Die Geschichtsbezogenheit des Heils und das Problem der Heilsgeschichte in der biblischen Tradition und in der theologischen Deutung, ed. Jörg Frey, et al., vol. 248 of Wissenschaftliche Untersuchungen Zum Neuen Testament (Tübingen: Mohr Siebeck, 2009). On the implications of one's choice in terminology, see especially Christoph W. Stenschke, review of Heil und Geschichte in Review of Biblical Literature 12 (June, 2010), pp. 4-5 (emphasis added); accessed July 31, 2010, http://www.bookreviews.org: "It will be difficult for scholars to reappropriate a concept of salvation history when they are at the same time convinced that most of the foundation of this concept, namely, God's interventions in history for salvation, did not happen and could not have happened in the way that they are recounted in the biblical tradition. In addition to the staunch opponents of salvation history (for this and other reasons), a notion of salvation and myth or salvation mythology is argued for in many quarters of biblical studies, in which the discipline is understood in terms of examining how this myth was formed (by drawing on historical notions and ideas) and how it functioned for the communities that created it." See further Karl-Heinz Schlaudraff, "Heil als Geschichte"? Die Frage nach dem heilsgeschichtlichen Denken, dargestellt 
anhand der Konzeption Oscar Cullmanns, vol. 29 in Beitrage zur Geschichte der biblischen Exegese (Tübingen: Mohr [Siebeck], 1988), esp. 117-46; J. A. Kelhoffer, "The Struggle to Define Heilsgeschichte: Paul on the Origins of the Christian Tradition," Biblical Research 48 (2003): 45-67.

61. See B. Ehrman, God's Problem: How the Bible Fails to Answer Our Most Important Question - Why We Suffer (New York: HarperOne,
2008). Ehrman gives attention to the historical "Jesus as an apocalypticist" (219-25), the Synoptic Gospels (very briefly, on 233-35), Paul (236-46, although only 244-46 discuss Paul on suffering), Revelation (246-55), and the Fourth Gospel (256-58). In a popular book, such as God's Problem, Ehrman offers only cursory discussions of the NT literature; however, to say that he just scratches the surface of this rich and multifaceted topic would be an understatement. 